Winter 2002

\title{
Treaties, Sovereign Immunity, and the Plan of the Convention
}

Susan Bandes

DePaul College of Law

Follow this and additional works at: https://via.library.depaul.edu/lawfacpubs

Part of the Law Commons

\section{Recommended Citation}

Susan Bandes, Treaties, Sovereign Immunity, and the Plan of the Convention, 42 Va. J. Int'I L. 743 (2002).

This Article is brought to you for free and open access by the College of Law at Digital Commons@DePaul. It has been accepted for inclusion in College of Law Faculty by an authorized administrator of Digital Commons@DePaul. For more information, please contact digitalservices@depaul.edu. 


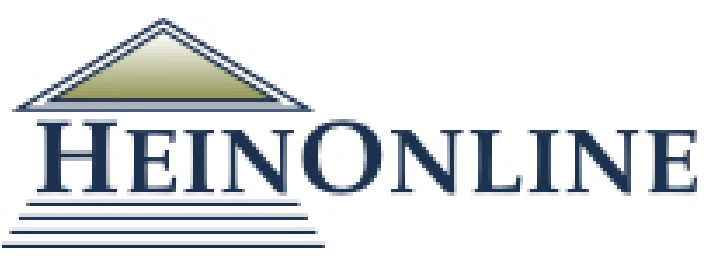

Content downloaded/printed from

HeinOnline

Wed Sep 18 14:54:14 2019

Citations:

Bluebook 20th ed.

Susan Bandes, Treaties, Sovereign Immunity, and the Plan of the Convention, 42 Va. J. Int'I L. 743 (2002).

APA 6th ed.

Bandes, S. (2002). Treaties, sovereign immunity, and the plan of the convention.

Virginia Journal of International Law, 42(2), 743-756.

ALWD

Bandes, S. (2002). Treaties, sovereign immunity, and the plan of the convention. Va.

J. Int'I L., 42(2), 743-756.

Chicago 7th ed.

Susan Bandes, "Treaties, Sovereign Immunity, and the Plan of the Convention,"

Virginia Journal of International Law 42, no. 2 (Winter 2002): 743-756

McGill Guide 9th ed.

Susan Bandes, "Treaties, Sovereign Immunity, and the Plan of the Convention" (2002) 42:2 Va J Intl L 743.

MLA 8th ed.

Bandes, Susan. "Treaties, Sovereign Immunity, and the Plan of the Convention."

Virginia Journal of International Law, vol. 42, no. 2, Winter 2002, p. 743-756.

HeinOnline.

OSCOLA 4th ed.

Susan Bandes, 'Treaties, Sovereign Immunity, and the Plan of the Convention' (2002) 42 Va J Int'I L 743

Provided by:

Rinn Law Library

-- Your use of this HeinOnline PDF indicates your acceptance of HeinOnline's Terms and Conditions of the license agreement available at https://heinonline.org/HOL/License

-- The search text of this PDF is generated from uncorrected OCR text.

-- To obtain permission to use this article beyond the scope of your license, please use: Copyright Information

Use QR Code reader to send PDF to your smartphone or tablet device

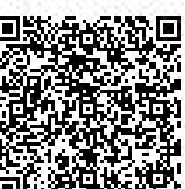




\title{
Treaties, Sovereign Immunity, and "The Plan of the Convention"
}

\author{
SUSAN BANDES ${ }^{*}$
}

\section{TABLE OF CONTENTS}

Introduction

I. The Power of Treaties to Abrogate State Sovereign Immunity Under Current Doctrine.

II. Beyond the Hypothetical: Real World Problems With

Abrogation Theory for Treaties and Statutes ............................... 749

A. The Supremacy Strain.......................................................750

B. The State Sovereignty Strain ............................................ 755

\section{INTRODUCTION}

This most recent addition to Carlos Vazquez's impressive body of Eleventh Amendment scholarship is; like his earlier work, both learned and provocative. As the doctrine in this field evolves, devolves, or selfdestructs so rapidly, depending on one's perspective, it is tremendously helpful to be privy to the running commentary of such a keen and watchful scholar.

In this paper, Vazquez asks: assuming the correctness of the Supreme Court's current sovereign immunity doctrine, should treaties be treated differently, from federal statutes when determining whether they abrogate state sovereign immunity? This is a question that federal courts scholars might consider rather narrow-a point I will return to later. ${ }^{1}$ It appears that the resonance of this question for those steeped in international law, at first blush at least, is greater.

As law professors we are used to having questions posed to us with certain assumptions appended, certain questions taken off the table. The

\footnotetext{
* Professor of Law, DePaul University. I wish to thank Curtis Bradley for conceiving of this conference, and Cherif Bassiouni, Brian Havel, and Spencer Waller for their insightful comments on earlier drafts of this paper.

1. See infra Part II.
} 
particular assumption from which Vazquez wishes to begin-that current sovereign immunity doctrine is correct-I find a particularly bitter pill to swallow, yet it would seem that accepting the assumption is a useful way to focus on the question of treaties versus statutes. I will begin by doing so, but later on I will suggest that the notion of a fixed "sovereign immunity doctrine" is descriptively problematic. I will also suggest, and here I think Vazquez and I are in agreement, that the narrow question about treaties cannot be usefully considered without turning to the broader questions of the scope and correctness of current sovereign immunity doctrine. Thus I will begin by considering the question as posed: assuming the validity of current doctrine, should treaties be treated like federal statutes when deciding whether they abrogate sovereign immunity? I will then turn to the problems inherent in the question posed.

\section{The Power of Treaties to Abrogate State Sovereign IMMUNITY UNDER CURRENT DOCTRINE}

Vazquez posits that, in light of current doctrine, the best argument for according treaties broader power to abrogate sovereign immunity is what he calls a "foreign affairs exceptionalism" argument, based on Missouri v. Holland. ${ }^{2} \mathrm{He}$ concludes that foreign affairs exceptionalism is not justified in this case; that the Constitution treats statutes and treaties the same with respect to remedies, and therefore that both sources of power should be subject to the same constitutional limits on their ability to abrogate. ${ }^{3}$ I will argue that one need not reach the question of foreign affairs exceptionalism at all in order to justify separate treatment of treaties.

Vazquez convincingly argues that the Holland case should be understood as holding that the limits on congressional power found in Article I section 8 are not applicable to Congress's treaty power, which arises from a wholly separate source. He goes on to say, however, that "[i]t does not follow that general limitations found elsewhere in the Constitution do not apply to the Treaty Power." $\mathrm{He}$ concludes that although the Founders were centrally concerned with enforcing state compliance with treaties, the mechanisms they chose for doing so were identical to those they chose for enforcing federal statutes: the

2. 252 U.S. $416(1920)$.

3. Carlos Manuel Vazquez, Treaties and the Eleventh Amendment, 42 VA. J. INT'L L. 713, 741 (2002).

4. Id. at 731 . 
Supremacy Clause and Article III, neither of which distinguishes statutes from treaties. ${ }^{5}$ Therefore, he argues, constitutional limitations on the federal statutory power to abrogate must apply equally to the treaty power.

But one does not have to join the fray about the proper interpretation of Missouri v. Holland (and indeed one can wholly agree with Vazquez's interpretation of Holland) to claim that this argument misapprehends current sovereign immunity doctrine. The notion of a generally applicable sovereign immunity doctrine is at odds with the current doctrinal understanding, which is highly clause-bound. ${ }^{6}$ In determining the scope of the abrogation power, it is essential to identify the authority under which Congress acted in order to know whether its attempt to subject the states to damage remedies is constitutional. ${ }^{7}$ That is, Vazquez's insight about the meaning of Holland - that it simply held that each source of Congressional power must be evaluated on its own terms ${ }^{8}$-is equally applicable to interpreting the scope of Congressional power to abrogate sovereign immunity. Whereas major federal statutes were once allowed the luxury of ambiguity about their precise source of federal authority, the Seminole Tribe decision ${ }^{9}$ has made identification of the source of Congressional power to abrogate crucial. Seminole Tribe disallowed abrogation under the Commerce Power, and reaffirmed Congress's power to abrogate under Section Five of the Fourteenth Amendment. ${ }^{10}$ In short, it is no longer possible to discuss the contours of a broad abrogation power without reference to the source of the power to abrogate.

Vazquez approaches the clause-bound nature of abrogation as if it is inapplicable to the treaty question because he characterizes current doctrine as accepting the chronology argument. That is, he interprets Seminole Tribe and its progeny to hold that only the Fourteenth Amendment, or at least only constitutional provisions passed subsequent to the Eleventh Amendment, may abrogate sovereign immunity, and concludes that since the treaty power falls on the wrong side of the divide, it cannot be used to abrogate. ${ }^{11}$ This is a defensible

\footnotetext{
5. Id. at 733 .

6. Vicki C. Jackson, Holistic Interpretation: Fitzpatrick v. Bitzer and Our Bifurcated Constitution, 53 STAN. L. REV. 1259, 1260 (2001).

7. Id. at 1264.

8. See also Carlos Manuel Vazquez, Breard, Printz, and the Treaty Power, 70 U. CoLo. L. REV. 1317, $1339 \mathrm{n.76}$ (1999) (discussing differences in treaty and statute as sources of power).

9. Seminole Tribe of Florida v. Florida, 517 U.S. 44 (1996).

10. Id. (reaffirming Fitzpatrick v. Bitzer, 427 U.S. 445 (1976)).

11. Vazquez, supra note 3, at 726-27.
} 
interpretation of Seminole Tribe but by no means the only possible interpretation. More significant, it conflicts with other important aspects of the Court's current approach to abrogation.

It is possible to read Seminole Tribe to stand for the broad proposition that only constitutional amendments passed subsequent to the Eleventh Amendment can override state sovereign immunity. The opinion contains language disclaiming the relevance of the rationale of Fitzpatrick v. Bitzer to Commerce Clause suits, since "Fitzpatrick cannot be read to justify limitation of the principle embodied in the Eleventh Amendment through appeal to antecedent provisions of the Constitution." ${ }^{\prime 2}$ But the fact that the Fitzpatrick decision, which after all considered only the propriety of a Fourteenth Amendment claim, cannot be relied on to justify an appeal to antecedent provisions does not mean that the appeal cannot be justified.

Seminole Tribe can also be read to declare that Article I is no longer a legitimate source of Congressional power for abrogating sovereign immunity. It contains language that "Article I cannot be used to circumvent the constitutional limitations placed upon federal jurisdiction." ${ }^{13}$ As Professor Fletcher recently observed, however, this language probably should not be taken literally, ${ }^{14}$ given the possibility of overriding sovereign immunity (albeit under a "waiver" rather than an "abrogation" rationale) under the Spending Clause. ${ }^{15}$

Seminole Tribe holds that the states shall be immune from unconsenting suit, "save where there has been a surrender of this immunity in the plan of the convention." power at the time of the framing of the Constitution remains an important inquiry. Alden v. Maine subsequently elaborated on this principle, referring to the "settled doctrinal understanding. .. that sovereign immunity derives not from the Eleventh Amendment but

12. 517 U.S. at 66 (quoting Pennsylvania v. Union Gas, 491 U.S. 1, 42 (1989) (Scalia, J., dissenting)).

13. Id. at 72.

14. William A. Fletcher, The Eleventh Amendment: Unfinished Business, 75 NOTRE DAME L. REV. 843, 853 (2000).

15. See, e.g., Litman v. George Mason University, 186 F.3d 544 (4th Cir. 1999) (finding waiver); Cherry v. University of Wisconsin System Bd. of Regents, 265 F.3d 541 (7th Cir. 2001) (same); Westside Mothers v. Haveman, 133 F. Supp. 2d 549 (E.D. Mich. 2001) (holding that waiver under Spending Clause may occur under the proper circumstances); see also Daniel J. Meltzer, State Sovereign Immunity: Five Authors in Search of a Theory, 75 NOTRE DAME L. REV. 1011, 1064 n.211 (raising question of effect of Spending Power on sovereign immunity); CHOPER, FALLON, KAMISAR \& SHIFFRIN, CONSTITUTIONAL RIGHTS AND LIBERTIES 1423 (9th ed. 2001) (same).

16. 517 U.S. at 68 (internal quotations omitted). 
from the structure of the original Constitution itself."17 The Court went on to explain that " $[t]$ he Eleventh Amendment confirmed rather than established sovereign immunity as a constitutional principle; it follows that the scope of the States' immunity from suit is demarcated not by the text of the Amendment alone but by fundamental postulates implicit in the constitutional design." ${ }^{\prime 18}$ Nor, the Court in Alden made clear, is the principle directly related to the scope of Article III power; it is a separate and distinct structural principle inherent in our Constitutional system of federalism. ${ }^{19}$ In short, current abrogation doctrine seems to demand an inquiry into the structural principles inherent in our Constitutional system of federalism, and into exactly what notion of state sovereignty was agreed upon in the plan of the convention. Given the Court's repeated incantation of the "plan of the convention" and "inherent structural principles," it is unfortunate that it has provided little guidance about how these should be identified, apart from assuring us that they should not be defined to include suit against unconsenting states. Nevertheless, this is the task at hand.

Let me emphasize that I am striving at this point merely to describe current doctrine. Many fine scathing critiques of the Court's reasoning have been written, pointing out its manifold flaws. ${ }^{20}$ My point here is simply that even accepting the Court's doctrinal scheme, even accepting that it is coherent to speak of pre-existing states entering the Union with and retaining a sweeping sovereignty, ${ }^{21}$ even accepting that this preexisting sovereignty is somehow immune from the great shifts of power after the Civil War, ${ }^{22}$ it is still necessary to determine the current scope of state sovereignty by examining the "structural principles inherent in our system of federalism."23

Should the treaty power be equated with the Commerce Power as identically placed in the structure of the Constitution? Returning to my

17. Alden v. Maine, 527 U.S. 706, 728 (1999).

18. Id. at $728-29$.

19. Id. at 730 .

20. See, e.g., Vicki C. Jackson, Principle and Compromise in Constitutional Adjudication: The Eleventh Amendment and State Sovereign Immunity, 75 NOTRE DAME L. REV. 953 (2000); Evan H. Caminker, "Appropriate" Means-Ends Constraints on Section 5 Powers, 53 STAN. L. REV. 1127 (2001); Louise Weinberg, Of Sovereignty and Union: The Legends of Alden, 76 Notre DAME L. REV. 1113 (2001); Alden v. Maine, 527 U.S. at 760 (Souter, J., dissenting).

21. See, e.g., Weinberg, supra note 20 , at $1153-55$ (critiquing notion of pre-existing states with sovereign power).

22. Jackson, supra note 6, at 1277 (arguing that the specifically enumerated powers of Article I may, like Congress's Section Five powers, also be considered more broadly in light of later enacted powers).

23. Id. See also Alden v. Maine, 527 U.S. at 713-14. 
original point, one need not argue for treaty power exceptionalism in order to maintain that the Treaty Power differs from the Commerce Power in significant ways, and that each should be considered separately. Indeed, I fear that the notion of treaty power exceptionalism may become a distracting semantic red flag, disguising that much narrower proposition. My aim here is not to prevail in the argument that the Treaty Power should be treated differently from the Commerce Power, but more narrowly to argue that Vazquez is incorrect to equate them simply because both appear in the unamended Constitution, and are treated equally by the Supremacy Clause.

Treaties are different from federal statutes in obvious ways. Most important for our purposes, they are not an exercise of Congress's Article I power to legislate in enumerated areas, but of the President's Article II power, with the advice of the Senate. ${ }^{24}$ Alexander Hamilton called them a unique species of power that is neither legislative nor executive in nature..$^{25}$ As my colleague Brian Havel notes, "the international treaty... represents a conscious departure from the domestic route to legislation." ${ }^{26}$ Treaties contain, as Vazquez notes, structural safeguards that do not exist with respect to statutes. ${ }^{27}$ Thus at the very least we can say that in the plan of the convention, treaties were not viewed as simply another species of legislation, and were assigned a separate and even unique role in the constitutional structure. The extent to which this separate role dictates separate abrogation rules is the question that should be debated. There is ample evidence that the states' refusal to enforce treaties was "not only important in shaping constitutional reform [after the Articles of Confederation] but of overwhelming significance. ${ }^{28}$ There is evidence that; whether or not the federal government was to have exclusive power over foreign affairs, ${ }^{29}$

24. See Curtis A. Bradley, The Treaty Power and American Federalism, 97 MICH. L. REV. 389,458 (1998) (arguing that the same federalism limitations should be imposed on the treaty power as are imposed on Congress's Article I power).

25. See Brian F. Havel, The Constitution in an Era of Supranational Adjudication, 78 N.C. L. REV. 257, 331 n.289 (2000) (citing the Federalist No. 75).

26. Id. at 331 . Havel notes that treaties differ from legislation in at least three respects: "they are approved by only one House of Congress (the Senate); they cannot be adopted by Congress without the President's consent; and they assume the participation of foreign countries in the United States law-making process." Id. at 332.

27. Vazquez, supra note 3 , at $722-23,725$.

28. FREDERICK W. MARKS III, INDEPENDENCE ON TRIAL: FOREIGN AFFAIRS AND THE MAKING OF THE CONSTITUTION (1986), quoted in Martin S. Flaherty, History Right?: Historical Scholarship, Original Understanding, and Treaties as "Supreme Law of the Land," 99 COLUM. L. REV. 2095, 2119 (1999).

29. See, e.g., Ernest Young, Sorting Out the Debate Over Customary International Law, 42 VA. J. INT'L L. 365 (2002) (pointing out that state courts are permitted to enforce treaties, and that 
the states were intended to play a subservient role in that arena. ${ }^{30}$ Vazquez considers these and other arguments, suggesting that in the original plan, states were not meant to have the latitude to determine whether or not treaties were enforceable. Ultimately, however, he finds these arguments wanting in light of the fact that the Supremacy Clause is the sole means of enforcing treaties, and that it treats them just like statutes. But his conclusion begs the question of whether other structural principles were also intended, in the plan of the convention, to safeguard treaties against state incursion. ${ }^{31}$

\section{BEYOND THE HypothetiCAL: REAL WORLD PROBLEMS With ABROGATION THEORY FOR TREATIES AND STATUTES}

Although I have attempted to discuss the narrow question raised in light of current doctrine, there are serious problems with that endeavor. Vazquez's discussion illustrates the difficulties of even provisionally assuming the correctness, or perhaps the very existence, of a stable, discernible body of current sovereign immunity doctrine-when in fact many of those boundaries are shifting and contested. As Vazquez himself has been instrumental in explaining, current Eleventh Amendment doctrine is deeply schizophrenic. ${ }^{32}$ In an article explaining this schizophrenia, he described "two distinct and conflicting analytical strains,"33 a "supremacy" strain that stresses the practical insignificance of Eleventh Amendment immunity, and a "state sovereignty" strain that views the Eleventh Amendment as standing for a vital and important principle that must be safeguarded, even at the cost of remedying governmental wrongs. ${ }^{34}$

Vazquez rests much of his argument for treating statutes like treaties on their equal treatment in the Supremacy Clause, and on the primacy of that clause as a means of ensuring an acceptable level of state

there is no guarantee of federal uniformity in treaty interpretation).

30. Kenneth C. Randall, Foreign Affairs in the Next Century, 91 COLUM. L. REv. 2097, 2105 (1991) (reviewing LOUIS HENKIN, CONSTITUTIONALISM, DEMOCRACY, AND FOREIGN AFFAIRS (1990)).

31. For arguments that other structural principles were so intended, see, e.g., Havel, supra note 25, at 330-31, and David M. Golove, Treaty-Making and the Nation: The Historical

Foundations of the Nationalist Conception of the Treaty Power, 98 MICH. L. REV. 1075, 1089$1100(2000)$.

32. Carlos Manuel Vazquez, Eleventh Amendment Schizophrenia, 75 NOTRE DAME L. REV. 859 (2000).

33. Id. at 859 .

34. Id. at 859-60. 
compliance with federal law. ${ }^{35}$ But this argument will take different shapes depending on which strain of Eleventh Amendment jurisprudence is employed.

\section{A. The Supremacy Strain}

The supremacy strain assumes a utilitarian calibration of remedies, some sort of conscious effort to ensure that state autonomy is not achieved at the expense of too little remediation. ${ }^{36}$ According to this theory, the existence and efficacy of remedies is an essential part of the scope of the doctrine itself. That is, the doctrine will operate to ensure "necessary judicial means to assure compliance" with federal obligation..$^{37}$

Such a rule requires, as Vicki Jackson has pointed out, some baseline measure of what constitutes adequate remediation. ${ }^{38}$ To arrive at such a measure requires, in turn, a discussion of the very structural principles we discussed earlier. How much governmental accountability, how much state autonomy, is the constitutional structure designed to safeguard? What notion of sovereignty does it seek to protect? It requires a means of measuring whether adequate remediation, however quantified, is occurring. ${ }^{39}$ It may also require a discussion of treaties separate from statutes. For example, if the Constitution is meant to avoid concentrations of power, does the unique Executive-Senate ratification process raise questions different from those raised by bicameral Congressional enactments? Does the participation of foreign

\footnotetext{
35. Vazquez, supra note 3, at 733.

36. See Jackson, supra note 20 , at $\mathbf{9 8 6 - 8 7}$ (noting and questioning this assumption in Vazquez's work).

37. Vazquez, supra note 3, at 718 (citing Pennsylvania v. Union Gas Co., 491 U.S. 1 (1989) (Scalia, J., dissenting)).

38. See Jackson, supra note 20 , at $986-87$.

39. This will inevitably be a contested measure. For example, in his article What is Eleventh Amendment Immunity?, 106 YALE L.J. 1683 (1997), Vazquez expresses the view that sovereign immunity doctrine, to the extent it bars suit against the entity but permits suits against individual officials, merely precludes vicarious liability, since "government liability is always vicarious liability, as governments, like corporations, are a legal fiction...." Id. at 1804 (citing Larry Kramer \& Alan O. Sykes, Municipal Liability Under 1983: A Legal and Economic Analysis, 1987 SUP. CT. REV. 249 (1987)). I would argue that this formulation misapprehends the nature of governmental liability, and the important ways in which it reaches the entity and its systemic constitutional violations, as opposed to the actions of individual employees. See Susan Bandes, Patterns of Injustice: Police Brutality in the Courts, 47 BUFF. L. REV. 1275, 1330-31 (1999); Susan Bandes, The Negative Constitution: A Critique, 88 MICH. L. REv. 2271, 2320-23 (1990); see also Daniel J. Meltzer, State Sovereign Immunity: Five Authors in Search of a Theory, 75 NOTRE DAME L. REV. 1011, 1016-17 (2000) (critiquing Alden decision and arguing for superiority of enterprise liability).
} 
governments in treaties, or the effect of violating treaties on our nation's place in the world, change the autonomy/accountability balance $?^{40}$ Given the increasing possibility of overlap between treaties and domestic law, ${ }^{41}$ what role should federalism play when state law threatens national compliance with international treaty negotiations and obligations? $?^{42}$

The inquiry must also extend to the current application of those other doctrines that are claimed to ameliorate the harshness of abrogation doctrine, particularly the doctrine of Ex parte Young. ${ }^{43}$ With regard to Ex parte Young, I think Vazquez is unduly sanguine about its continued ability to safeguard the Supremacy Clause. Although it could once be said with some assurance that the doctrine was meant to safeguard the supremacy of federal law, ${ }^{44}$ cases like Seminole Tribe and Idaho $v$. Coeur d'Alene Tribe of Idaho, ${ }^{45}$ or at least language in those decisions, bode ill for continued broad reliance on its use. As these cases make clear, the Ex parte Young doctrine, like the abrogation doctrine, is applied in an increasingly clause-bound manner. That is, whether it safeguards the supremacy of federal law will depend on the source of the law. ${ }^{46}$ It may be evolving into a narrower utilitarian rule solely

40. Vazquez notes that violations of treaties adversely affect a nation's reputation for keeping its promises, and may also subject the nation as a whole to retaliation. Vazquez, supra note 3, at 729. As Robert Wright recently argued, not only the balance of states versus federal sovereignty, but the scope of national sovereignty itself, must be debated anew in light of the importance of international treaties to the effort to address modern global threats to our security as a nation. See Robert Wright, America's Sovereignty in a New World, N.Y. TIMES, Sept. 24, 2001, at A31.

41. Louis Henkin, Human Rights and State Sovereignty, 25 GA. J. INT'L \& COMP. L. 31,31 (1995-96). For recent examples of arguments that international treaties ought to be applicable in particular state law contexts, see Maria V. Morris, Racial Profiling and International Human Rights Law: Illegal Discrimination in the United States, 15 EMORY INT'L L. REV. 207 (2001); Elizabeth A. Reimels, Playing for Keeps: The United States Interpretation of International Prohibitions Against the Juvenile Death Penalty-The U.S. Wants to Play the International Human Rights Game, but Only if it Makes the Rules, 15 EMORY INT'L L. REV. 303 (2001).

42. See, e.g., Crosby v. National Foreign Trade Council, 530 U.S. 363 (2000) (holding that Massachusetts's "Burma Law," which conflicted with the Uruguay Round Agreements Act, and which prohibited the state and its agents from purchasing goods or services from anyone doing business with the Union of Myanmar, was preempted, and its application unconstitutional, under the Supremacy Clause).

43. 209 U.S. 123 (1908).

44. Vicki Jackson, Seminole Tribe, the Eleventh Amendment, and the Potential Evisceration of Ex Parte Young, 72 N.Y.U. L. REV. 495, 512 (1997) (noting that the Pennhurst case cast the Ex parte Young doctrine as based on the needs of national supremacy).

45. 521 U.S. 261 (1997).

46. See Seminole Tribe of Florida .v. Florida, 517 U.S. 44 (1996) (discussing doctrine's application to Indian Commerce Clause); Pennhurst v. Halderman, 465 U.S. 89 (1984) (discussing doctrine's application to Fourteenth Amendment); see also David Shapiro, Wrong Turns: The Eleventh Amendment and the Pennhurst Case, 98 HARV. L. REV. 61, 83-84 (1984) (noting Pennhurst Court's frank acknowledgement of Ex parte Young doctrine's practical purpose 
designed to safeguard the Fourteenth Amendment, ${ }^{47}$ or to be used only when "necessary." 48 It may be evolving from a utilitarian rule meant to safeguard supremacy into a rule that operates only when the suit is not "really" against the state. ${ }^{49}$ Thus we cannot assume that it will be held to safeguard supremacy equally for treaties and statutes, or even for all federal statutes, or even that it will be applied uniformly under any particular federal statute.

The supremacy strain, with its focus on actual remediation, also demands an inquiry into how the balance of federal supremacy and state autonomy works in practice under a particular remedial regime. ${ }^{50}$ Here is another context in which treaties and statutes should not be automatically equated. The question should be: has state autonomy been inadequately protected against incursions by treaties or statutes? As to treaties, Vazquez notes the threat to federalism posed by, for example, broad and vaguely worded treaties protecting human rights. ${ }^{51}$ Yet the current evidence points away from such a threat. As Jack Goldsmith observes, the political branches often choose to protect state interests over foreign relations when the two appear to clash. ${ }^{52} \mathrm{He}$ notes that "even when the political branches enact preemptive federal foreign relations law, they often do so in a manner that reflects the interests of the states and minimizes intrusions on their prerogatives." ${ }^{33}$ Louis Henkin similarly observes that the Senate substantially represents the states against internationalist federal regulation, and has often protected their interests and adopted their views, ${ }^{54}$ as it did, for example, in the Uruguay Round Agreements Act, ${ }^{55}$ which, as Henkin summarizes,

of enforcing supremacy of federal law).

47. See Carlos Manuel Vazquez, Night and Day: Coeur d'Alene, Breard, and the Unraveling of the Prospective-Retrospective Distinction in Eleventh Amendment Doctrine, 87 GEO. L.J. 1, 45 (1998) (noting Justice Kennedy's suggestion that Milliken v. Bradley can be explained in this way).

48. See Jackson, supra note 42, at 512 (suggesting that in the Article I context, Ex parte Young has been reduced to virtually a doctrine of necessity.)

49. Vazquez, supra note 45, at 48; Coeur d'Alene, 512 U.S. at 270.

50. See Bradley, supra note 24 , at 442 (arguing that we should examine the way in which the Senate currently works to protect treaties, and pointing to its changed role in this context since the time of the Framers).

51. Vazquez, supra note 3, at 723.

52. He offers the example of international human rights treaties to which the President and Senate, despite international pressures, have consistently attached reservations, understandings and declarations to ensure they do not preempt inconsistent state law. Jack L. Goldsmith, Federal Courts, Foreign Affairs, and Federalism, 83 VA. L. REv. 1617, 1675 (1997) (making these observations in context of an argument for less judicial supervision of treaties)

53. Id.

54. LOUIS HENKIN, FOREIGN AFFAIRS AND THE U.S. CONSTITUTION 168 ( $2 \mathrm{~d}$ ed. 1996).

55. 19 U.S.C. $\S \S 3501$ et seq. (Supp. IV 1998) (establishing World Trade Organization). 
provides:

that the agreement shall not itself violate state law, but requires an act of Congress to achieve that end. The Act also provides that the courts may invalidate state law on the ground that it is inconsistent with the Agreement only in an action brought by the federal government for that purpose. Congress also provided a role for the states in the dispute settlement process. ${ }^{56}$

I recognize that as a theoretical matter the "political safeguards" argument is controversial, ${ }^{57}$ but my point here is that in evaluating sovereign immunity doctrine within a utilitarian framework like the "supremacy strain," one must assess how, in fact, those safeguards have been working.

An additional practical question arises in this assessment process. As Vazquez observes, "few treaties address domestic remedies. . . and even fewer are so specific as to require remedies against the state itself as opposed to officials." "58 It appears that, as to treaties, the question of abrogation simply does not come up very often. The problem is far more immediate in regard to federal statutes. Within just the last five years, the Court has precluded Congress from abrogating sovereign immunity, despite its clear intent to do so, under the Indian Gaming Regulatory Act, ${ }^{59}$ the Patent and Plant Variety Protection Remedy Clarification Act, ${ }^{60}$ the Trademark Remedy Clarification Act, ${ }^{61}$ the Fair

56. HENKIN, supra note 54, at 169.

57. The well-known argument that federalism is adequately safeguarded by the political branches was most famously made by Herbert Wechsler. See Herbert Wechsler, The Political Safeguards of Federalism: The Role of the States in the Composition and Selection of the National Government, 54 CoLUM. L. REV. 543 (1996). A recent prominent article advancing this position is Larry D. Kramer, Putting the Politics Back into the Political Safeguards of Federalism, 100 COLUM. L. REV. 215 (2000). Henkin relies on this argument in the treaty context. See Henkin, supra note 52, at 168. Curtis Bradley argues at length against its application to treaties, though he concedes that in practice Congress has consistently refused to displace state law with international human rights obligations. See Bradley, supra note 24, at 440-44; Curtis A. Bradley, The Treaty Power and American Federalism, Part II, 99 MICH. L. REV. 98, 108 (2000). See also John C. Yoo, Judicial Review and Federalism, 22 HARV. J.L. \& PUB. POL'Y 197, 197 (1998) (agreeing that the Framers believed in the political safeguards of federalism, but arguing that they did not consider these safeguards to exclude judicial review). But see Golove, supra note 31 , at 1294-99 (arguing for the recognition of the special political protections afforded to state interests in the treaty-making process).

58. Vazquez, supra note 3 , at 742 .

59. Seminole Tribe v. Florida, 517 U.S. 4 (1996).

60. Florida Prepaid Postsecondary Educ. Expense Bd. v. College Savings Bank, 527 U.S. 627 (1999).

61. College Sav. Bank v. Florida Prepaid Postsecondary Educ. Expense Bd., 527 U.S. 666 (1999). 
Labor Standards Act, ${ }^{62}$ the Age Discrimination in Employment Act, ${ }^{63}$ and the Americans With Disabilities Act ${ }^{64}$ I will not here catalogue the wide ranging and impressive body of scholarship expressing not just criticism of but alarm at the Court's increasing willingness to use sovereign immunity doctrine to override federal law. ${ }^{65}$

The immediate point I underline here is that if we are to ask how current sovereign immunity doctrine is working in practice, the answer is not the same for treaties and statutes. The concerns about treaties seem at this point largely theoretical. ${ }^{66}$ The concern about statutes is immediate and serious. Many scholars, and I count myself among them, believe that the supremacy of federal statutory law is severely threatened under the current doctrinal regime. As I observed elsewhere:

[The Court's sovereign immunity jurisprudence] relies on an expansive version of sovereign immunity whose claimed immanence is such that it supersedes the limitations imposed by the language of the Constitution, and trumps, without any justification beyond its existence, weighty countervailing principles like governmental accountability and the supremacy of federal law. The Court has done much to 'denationalize' [citation omitted] systematic federal protection of core federal rights, and has done so without acknowledging that the importance of according federal protection to such rights ought to be part of the equation. ${ }^{67}$

The larger point, however, is one with which I believe Vazquez

62. Alden v. Maine, 527 U.S. 706 (1999).

63. Kimel v. Florida Bd. of Regents, 528 U.S. 62 (2000).

64. Board of Trustees of the University of Alabama v. Garrett, 531 U.S. 356 (2001).

65. See, e.g., Caminker, supra note 20; Jackson, supra note 20; Weinberg, supra note 20.

66. Bradley, for example, concedes that Congress has been quite protective of state autonomy in the treaty context, but bases his rejection of the "political safeguards" argument in part on the speculative concern that the Senate may not continue to act this way in the future. Bradley, supra note 24, at 444. In addition, as Vazquez acknowledges, "[m]any of the 'treaties' often invoked as sources of a congressional power to abrogate state sovereign immunity are actually congressional-executive agreements." Vazquez, supra note 3, at 725. David Bederman states that "the number of treaties submitted to the Senate for advice and consent has dwindled, while... executive agreements have flourished. As of the 1990s, the United States had concluded less than 1500 treaties, while it had entered into over 10,000 executive agreements." DAVID J. BEDERMAN, INTERNATIONAL LAW FRAMEWORKS 166 (2001). See also Peter J. Spiro, Treaties, Executive Agreements, and Constitutional Method, 79 TEX. L. REV. 961, 964-65 (2001) (noting that "some of the nation's most important postwar undertakings have taken such a form"). Vazquez explicitly exempts these congressional-executive agreements from his analysis, recognizing their distinct constitutional character. Vazquez, supra note 3, at 725.

67. Susan Bandes, Erie and the History of the One True Federalism, 110 YALE L.J. 829, 876 (2001). 
would agree. Treaty exceptionalism, or indeed any separate treatment of treaties, will not address the real question of inadequate remediation for violations of statutory law. ${ }^{68}$ If the Court is serious about ensuring adequate remediation, it must rethink a calibration effort that has gone seriously awry.

\section{B. The State Sovereignty Strain}

There is an even more serious problem with assuming a stable doctrinal framework for this discussion of treaties and statutes-specifically, the very schizophrenia Vazquez identifies. What version of sovereign immunity doctrine are we talking about, exactly? Though Vazquez expresses concern about the Court's increased allegiance to the state sovereignty strain, ${ }^{69}$ he is nevertheless too optimistic about the continued existence of the supremacy strain. Alden is simply the most recent and most emphatic statement of the Court's deeply held belief that sovereign immunity is a deep, structural, first order principle that must be protected irrespective of whether it leaves an injured party remediless. ${ }^{70}$ This belief permeates the Court's increasingly aggressive applications of sovereign immunity doctrine to bar Congressional abrogation, and is becoming more and more visible in its steady contraction of the doctrine of Ex parte Young. ${ }^{71}$

If indeed sovereign immunity law now rests, or increasingly rests, on this uncompromising principle, what lessons should we draw for the question Vazquez posed: whether treaties have more power than statutes to abrogate the Eleventh Amendment? As he recognizes, if I may put the matter colloquially, at that point the difference between treaties and statutes becomes the least of our problems. A doctrine that does violence to our ability to enforce the rule of law or guarantee the supremacy of federal law against state government is itself a threat to our sovereignty as a nation-albeit a threat with domestic origins. As

68. See generally Vazquez, supra note 3 .

69. Id. at 25 " Of greater concern is language in some recent decisions suggesting that the Court is departing from the [Supremacy] view. ..").

70. See Jackson, supra note 20 , at 953 (critiquing expansion of sovereign immunity into a first order principle); see also Daniel A. Farber, Pledging a New Allegiance: An Essay an Sovereignty and the New Federalism, 75 NOTRE DAME L. REV. 1133, 1144 (2000) (referring to Court's "reverential" attitude toward sovereign immunity); Matthew Mustokoff, Sovereign Immunity and the Crisis of Constitutional Absolutism: Interpreting the Eleventh Amendment after Alden v. Maine, 53 ME. L. REV. 81, 83 (2001) (referring to recent cases culminating in Alden as "broaden[ing] the Eleventh Amendment from a procedural rule of narrow, precise application to an overriding, absolute principle of state sovereign immunity ... [a] fundamental, unwavering precept of universal recognition").

71. See supra text accompanying notes 43-49. 
Kenneth Randall observed, ours is not only a constitutional system, but a democratic one, in which "individuals retain the rights the government should secure, even against their representatives in government." this broad question, at least, Vazquez and I appear to agree. If this is an accurate description of our current situation, it cannot be solved through half-measures. Current sovereign immunity doctrine itself must be rethought in light of the principles undergirding our aspirations for a "more perfect union." "73

72. Randall, supra note 30 , at 2100.

73. See Louis Henkin, Silbey Lecture, Human Rights and State 'Sovereignty,' March 1994, reprinted in adapted form at 25 GA. J. INT'L \& COMP. L. 31 (1995-96) ("In the United States, We the People asserted sovereignty not to maintain their natural liberty ('sovereignty') so as to be free from government, but to form and consent to a "more perfect union."). 